\title{
Young man with diabetic lipaemia
}

\author{
Manon G van der Meer, ${ }^{1}$ Gerben A J van Boekel, ${ }^{1}$ Lenneke E M Haas ${ }^{2}$
}

'Department of Internal Medicine, Diakonessenhuis Utrecht, Utrecht, The Netherlands

${ }^{2}$ Department of Intensive Care, Diakonessenhuis Utrecht, Utrecht, The Netherlands

\section{Correspondence to} Lenneke EM Haas, Ivlelyveld@diakhuis.nl

Accepted 30 May 2016

\section{DESCRIPTION}

A sample of lipaemic blood with total cholesterol (TC) of $1404 \mathrm{mg} / \mathrm{dL}(<251 \mathrm{mg} / \mathrm{dL})$ and triglycerides (TG) of $18601 \mathrm{mg} / \mathrm{dL}(<195 \mathrm{mg} / \mathrm{dL})$ is displayed in figure 1. Low-density lipoprotein and high-density lipoprotein could not be calculated due to interference with the extremely elevated TG level. The patient was a previously healthy 21-year-old man presenting to our emergency department, with diabetic ketoacidosis (DKA).

DKA is an acute metabolic complication of insulin deficiency, characterised by acidosis, hyperglycaemia and ketosis. It may occur in 30\% of patients with new onset type I diabetes. Insulin deficiency can lead to derangement in lipid metabolism resulting in lipolysis with excess production of fatty acid from adipose tissue and increased synthesis of TG. Severe hypertriglyceridaemia is a rare but well-recognised complication of DKA and is called 'diabetic lipaemia'. Previous case reports described patients with DKA and TG levels between 11758 and $33570 \mathrm{mg} / \mathrm{dL}^{1}{ }^{2}$ In all patients, the lipid levels normalised after treating

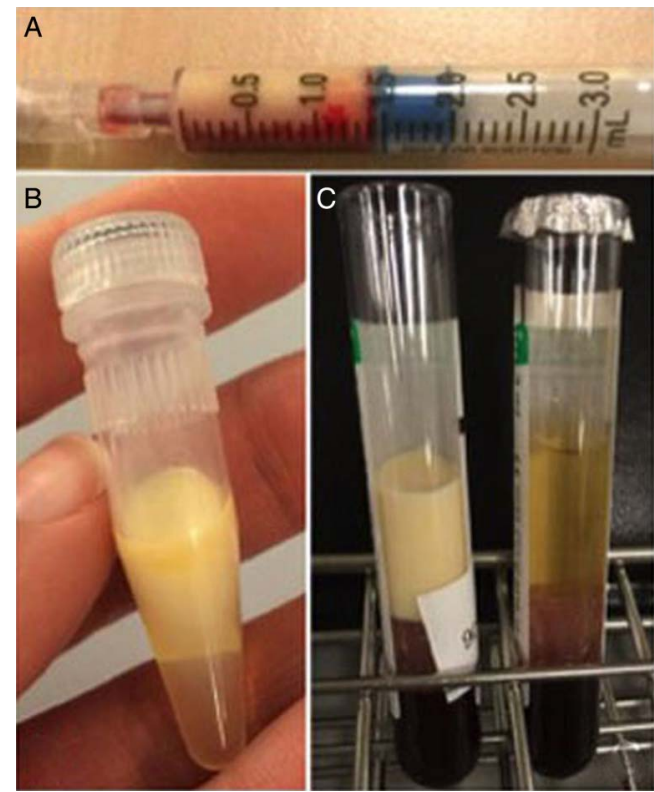

Figure 1 (A) Photograph of an arterial blood sample. (B) Photograph of a serum sample extracted by centrifugation from the venous blood sample. (C) Photograph of a venous blood sample. the DKA. ${ }^{1} 2$ The pathogenesis of diabetic lipaemia is not completely understood. Heterozygous mutations of lipoprotein lipase (LPL), a key insulindependent enzyme in degradation of TG, might play a role. ${ }^{2}$ However, the majority of patients with diabetic lipaemia did not have a genetic abnormality in the LPL. ${ }^{3}$

In our patient, TC decreased in 3 days to $963 \mathrm{mg} / \mathrm{dL}$, and TG to $5669 \mathrm{mg} / \mathrm{dL}$. Plasma glucose levels rapidly normalised with insulin therapy. After 4 weeks, the patient visited the outpatient clinic, with TC of $135 \mathrm{mg} / \mathrm{dL}$ and TG of $106 \mathrm{mg} / \mathrm{dL}$. The elevated TG resolved without an anti-lipid agent.

\section{Learning points}

Diabetic ketoacidosis can lead to an extreme dysregulation of lipid homeostasis, called diabetic lipaemia.

- The extremely elevated triglyceride levels can completely resolve by treating the diabetic ketoacidosis, without using an anti-lipid agent.

Acknowledgements The authors would like to thank Carola Hoek for supplying the photographs.

Contributors MGvdM was responsible for conception, design, acquisition of data, interpretation of data, drafting the article, revising the article and final approval of the manuscript. GAJvB took part in design, interpretation of data, revising the article and final approval of the manuscript. LEMH was responsible for conception, design, acquisition of data, interpretation of data, drafting the article, revising the article and final approval of the manuscript.

Competing interests None declared.

Patient consent Obtained.

Provenance and peer review Not commissioned; externally pee reviewed.

\section{REFERENCES}

1 Lucchetti G, Granero AL, Almeida LG, et al. [Severe hypertriglyceridemia in diabetic ketoacidosis: case report]. Arq Bras Endocrinol Metabol 2009;53:880-3.

2 McLean AG, Petersons CJ, Hooper AJ, et al. Extreme diabetic lipaemia associated with a novel lipoprotein lipase gene mutation. Clin Chim Acta 2009;406:167-9.

3 Radhakutty A, Shen J, Hooper AJ, et al. Quantification and genotyping of lipoprotein lipase in patients with diabetic lipaemia. Diabet Med 2014;31:1702-7. 


\section{Images in...}

Copyright 2016 BMJ Publishing Group. All rights reserved. For permission to reuse any of this content visit http://group.bmj.com/group/rights-licensing/permissions.

BMJ Case Report Fellows may re-use this article for personal use and teaching without any further permission.

Become a Fellow of BMJ Case Reports today and you can:

- Submit as many cases as you like

- Enjoy fast sympathetic peer review and rapid publication of accepted articles

- Access all the published articles

- Re-use any of the published material for personal use and teaching without further permission

For information on Institutional Fellowships contact consortiasales@bmjgroup.com

Visit casereports.bmj.com for more articles like this and to become a Fellow 